\title{
Techno-Economic Assessment of Non-Revenue Water: A Case Study at AER, GWCL
}

\author{
C. K. K. Sekyere ${ }^{1 *}$, F. Davis ${ }^{1}$, Y. A. K. Fiagbe1, R. N. G. Amoo ${ }^{2}$ \\ ${ }^{1}$ Department of Mechanical Engineering, KNUST, Kumasi, Ghana \\ ${ }^{2}$ Ghana Water Company Limited, ATMA Production, Accra, Ghana \\ Email: *ckksekyere.coe@gmail.com, *ckksekyere@knust.edu.gh, fkdav@yahoo.com, \\ yakfiagbe@yahoo.com,ransfordamoo@yahoo.com
}

How to cite this paper: Sekyere, C.K.K., Davis, F., Fiagbe, Y.A.K. and Amoo, R.N.G. (2020) Techno-Economic Assessment of Non-Revenue Water: A Case Study at AER, GWCL. Journal of Water Resource and Protection, 12, 480-494.

https://doi.org/10.4236/jwarp.2020.126029

Received: March 31, 2020

Accepted: June 5, 2020

Published: June 8, 2020

Copyright () 2020 by author(s) and Scientific Research Publishing Inc. This work is licensed under the Creative Commons Attribution International License (CC BY 4.0).

http://creativecommons.org/licenses/by/4.0/

\begin{abstract}
This study utilizes multiple regression analysis and the technique for computing economies of scale to evaluate the dynamics of NRW in the AER of GWCL. Data on monthly total production, billed consumption, total revenue, total production cost and the volume of NRW spanning the period January 2015 to June 2019, was obtained from the headquarters of AER and used for the analysis. The study showed that NRW averaged $40.3 \%$ for the period under consideration, which far exceeds the $25 \%$ threshold set by the World Bank for developing economies. It was also established that a fairly inelastic relationship exists between NRW and total revenue. Results further show that resources are not optimally used in the AER as proof of diseconomies of scale was observed.
\end{abstract}

\section{Keywords}

Non-Revenue Water, Coefficient of Elasticity of NRW, Economies of Scale, Accra East Region, Ghana Water Company Limited

\section{Introduction}

According to a Water Rights report [1], freshwater constitutes about 2.76 percent of the total water available on Earth. Global freshwater demand is projected to increase by $55 \%$ by the year 2050 [2]. This makes freshwater a very scarce resource, which needs to be well managed by man.

A large number of countries are experiencing water stress, and increasing drought and desertification is already worsening these trends. Approximately one-third of countries have medium or high levels of water stress. Almost all countries that have registered high water stress are located in North Africa and 
West Asia or in Central and South Asia, and these levels indicate serious water difficulties in the supply of freshwater, at least during parts of the year [3]. By 2050 , it is projected that at least one in four people will suffer recurring water shortages. One of the targets of the Sustainable Development Goal six (SDG 6) is to substantially increase water-use efficiency across all sectors and ensure sustainable withdrawals and supply of freshwater to address water scarcity and substantially reduce the number of people suffering from water scarcity by 2030 . To ensure universal safe and affordable drinking water, there is the need to invest in adequate infrastructure, provide sanitation facilities, and encourage good hygiene practices.

In Ghana, portable water is supplied by the Ghana Water Company Limited (GWCL), formally known as the Ghana Water and Sewerage Cooperation (GWSC) [4]. The company mainly provides water to the urban centers of the country and currently covers about 77 percent of the urban areas in Ghana. It supplies 192 million gallons of water per day, through eighty-eight (88) urban water supply systems, which is in excess demand of 57 million [5]. To ensure a sustainable production of water to its customers and to meet its projected targets, the company operates fifteen (15) regional offices which are distributed around the country. The offices include, the Accra East, Accra West, Ashanti South, Ashanti North, Ashanti Production, Western, Eastern, Brong Ahafo, Northern, Volta, Central, Upper East, Upper West, ATMA Production and Tema.

The GWCL assumed its current structure after it underwent a reformation period in the late 1990s. Prior to independence, the need to have a division to supply water to the colonial apparatus operating in the country at the time was acknowledged. Thus, the Hydraulic Water Division of the Public Works Department was established. After the attainment of independence in 1957, the water division was established under the Ministry of Works and Housing with a critical responsibility of supplying water to the rural and urban areas of the country. Following a recommendation of the World Health Organization (WHO), the GWSC was thus created by Act 310 in 1965.

Economic vulnerabilities in the 1970s and 1980s, together with deteriorated pipe connections and pumping systems impacted the performance of the Cooperation. As a result, the Water Resources Commission (WRC) and Public Utilities Regulatory Commission (PURC) were established in 1996 to regulate and value the supply of water in Ghana. The ensuing dynamics in the water supply industry, therefore, birthed the GWCL in 2005; when private hands were engaged to part own the company (GWCL, 2018).

One of the major reasons for privatizing the GWSC was the issue of NonRevenue Water (NRW) and its impacts on the operations of the water supplying organization [4] [6] [7]. Conceptually, NRW is water that has gone through all the production process but lost without generating revenue to the utility company. According to the International Water Association [8], NRW is "the difference between System Input Volume and Billed Authorized Consumption”. 
According to literature [4] [7] [9], non-revenue water can be organized into three main categories. These include; physical (real) losses, Apparent (commercial) losses and Unbilled Authorized Consumption. Physical water loss occurs when there are breakages, leakages, bursts, overflows pipelines and service reservoirs as well as service connections. Apparent or commercial loss of produced water can be attributed to meter reading errors, under-registering meters and water theft and billing errors. Unbilled Authorized Consumption does not provide direct revenue to the utility company and comprise of produced water used in such activities as firefighting and other national security operations. Previous NRW studies conducted in Ghana focused on the middle and northern parts of Ghana [4] [10]. The study focuses on the Accra East region of the Greater Accra region of GWCL. The Accra East region of the Ghana water company Limited (GWCL) serves the Dodowa, Adenta, Teshie, Nungua, Dome, Accra Central, Accra North, Kwabenya, Accra North East and Accra East districts of the Greater Accra region (see Figure 1 for location of Accra East Region). The dynamics of NRW have not been established for the Accra East Region which constitutes the largest GWCL administrative region in terms of urban water demand.

Thus, this study, therefore, seeks to fill the gap in terms of information on NRW dynamics by conducting a technical and economic assessment of NonRevenue Water (NRW) to ascertain the trends and its effect on production and

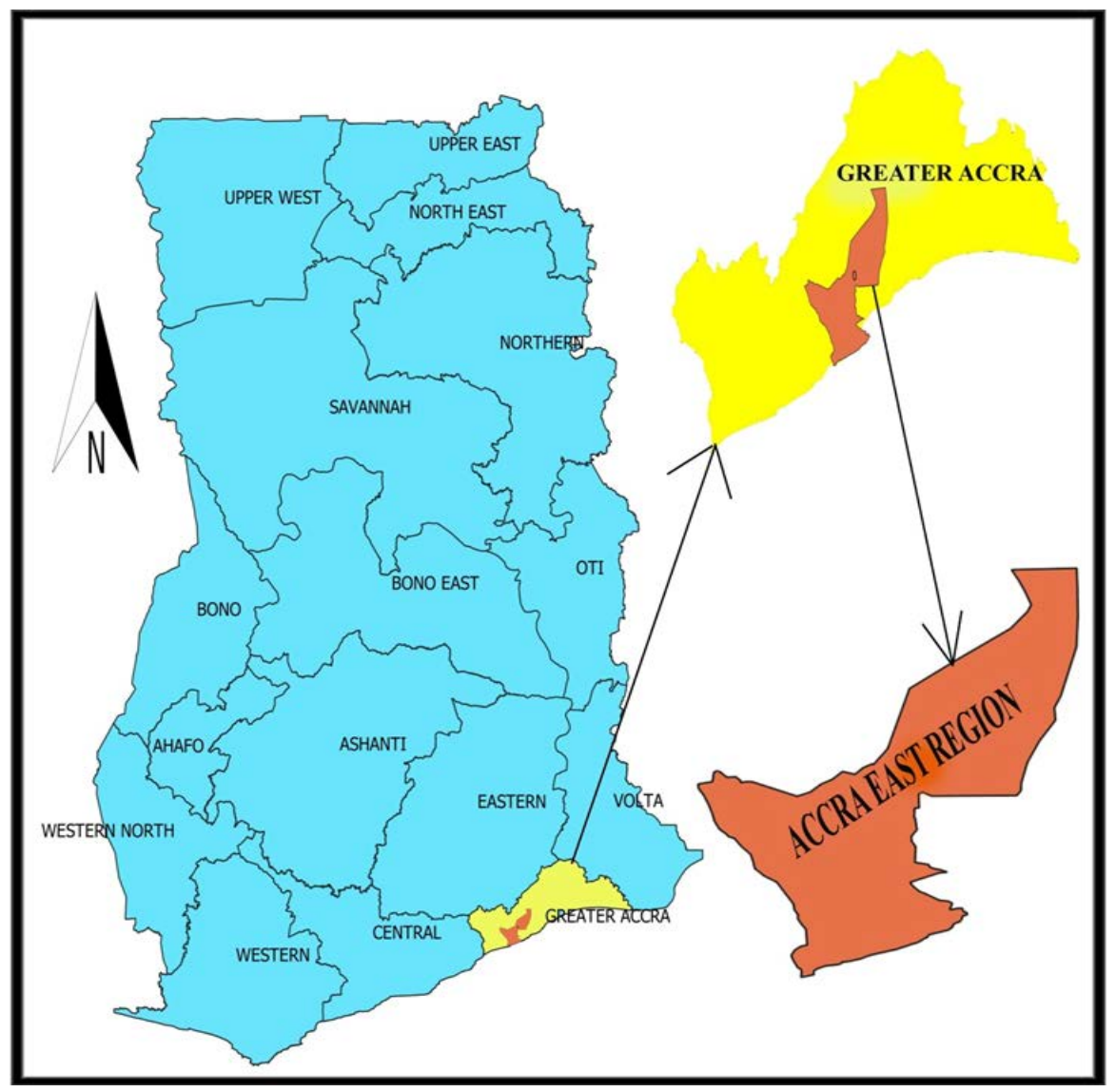

Figure 1. Map of Ghana showing Accra East Region of GWCL. 
cost structures of Accra East Region of the Ghana Water Company Limited (GWCL).

\section{Methodology}

\subsection{Theoretical Framework}

The magnitude of Non-Revenue Water (NRW) has grave consequences on the competitiveness and efficiency of water production and distribution companies. Large volumes of NRW constrain the financial ability of utility companies to embark on strategic projects such as network expansion, meter replacement and metering policies as well as improving operational efficiency. Furthermore, attempts to minimize the magnitude of NRW to acceptable levels require significant financial investment in fixing leakages and improving the database of customers as well as strengthening monitoring systems [7] [11].

Moreover, reducing NRW has significantly positive impact on the financial performance of utility companies. According to World Bank report [11], an economic optimum is achieved when the marginal cost of reducing non-revenue water exceeds the marginal benefits (water savings). Benefits derived from reducing NRW should be measured through decreased cost of production [11]. This is because reduction in NRW could lead to reduced volumes of water production to meet the demands and supply requirements of the service area. Besides, additional revenue could be generated through the sale of additional water captured from reduction in the volume of NRW [12] [13] [14] [15].

A study conducted on the evaluation of apparent water losses [16] emphasized that the reduction in the cost of production through reduction in NRW has little financial incentives for water service providers if volumetric tariffs are low (flat rate) and few or no metering systems available. Thus, from the economic perspective, minimizing NRW leads to decreased cost of production, increased volume of billed water and increased revenue generation. However, efforts must be made by utility service providers to charge economic rates on water usage as well as improve on the metering system in service areas [12] [15]. Thus, the implicit theoretical function for analysing NRW is shown in Equation (2.1):

$$
N R W=f(Q, T R, T C)
$$

where:

NRW $=$ Non-Revenue Water; $\mathrm{Q}=$ Total Volume of Production; $\mathrm{TR}=$ Total Revenue and TC $=$ Total Cost of Production.

\subsection{Trends in Non-Revenue Water}

The first objective of the study is to analyze the trends in Non-Revenue Water in the Accra East Region of the GWCL. The growth rates of non-revenue water are estimated to enable the utility company to realize its non-revenue water over time. In a discrete form, growth rate is calculated as the difference between current values and previous values all divided by the previous value. The result is 
then multiplied by $100 \%$ to provide an interpretation in percentage terms. The algebraic framework generating the growth rate is espoused as:

$$
\eta=\frac{N R W_{t}-N R W_{t-1}}{N R W_{t-1}} \times 100 \%
$$

where:

$\eta=$ the growth rate of Non-Revenue Water;

$N R W_{t}=$ Non-Revenue Water at time $t$,

$N R W_{t-1}=$ Non-Revenue Water at time $t-1$.

\subsection{Elasticity of Non-Revenue Water to Total Revenue and Production}

Elasticity measures the degree of sensitivity or responsiveness of a variable to another variable under consideration [16] [17]. The coefficient of elasticities provides a statistic to determine whether a variable is elastic or inelastic. To examine the elasticities of NRW to total revenue and production, two separate log-linear regression models are specified [17] [18]. These are expressed as follows:

$$
\begin{gathered}
\ln T R_{t}=\beta_{0}+\beta_{1} \ln N R W_{t}+\beta_{2} \ln Q_{t}+\varepsilon_{t} \\
\ln Q_{t}=\alpha_{0}+\alpha_{1} \ln N R W_{t}+\mu_{1}
\end{gathered}
$$

The elasticities are calculated as follows:

$$
\begin{gathered}
\gamma_{T R}=\frac{\delta \ln T R}{\delta \ln N R W} \\
\gamma_{Q}=\frac{\delta \ln Q}{\delta \ln N R W}
\end{gathered}
$$

where:

$\gamma_{T R}=$ the elasticity of Non-Revenue Water to total revenue;

$\gamma_{Q}=$ the elasticity of Non-Revenue Water to total production;

$\ln N R W_{t}=$ the natural logarithm of Non-Revenue Water at time $t$;

$\ln T R_{t}=$ the natural logarithm of total revenue at time $t$,

$\ln Q_{t}=$ the natural logarithm of total production at time $t$;

$\varepsilon_{t}$ and $\mu_{t}$ are the stochastic error terms;

$\beta_{i}$ and $\alpha_{i}$ are the parameter estimates.

A variable is said to be elastic if its coefficient of elasticity is greater than one. However, it is said to be inelastic if the coefficient of the variable is less than one [16] [17]. For instance, when a proportionate change in NRW leads to the same proportionate change in total revenue, the relationship is considered to be unitary elastic.

\subsection{Economies and Diseconomies of Scale}

Economies of scale are a long-run phenomenon in the production process of a firm. A firm enjoys economies of scale if expansion in production results in lower unit cost of production. Also, diseconomies of scale exist when expansion 
in production activities result in higher unit cost of production. However, resources are optimally employed when there exist neither economies of scale nor diseconomies of scale [16] [17] [19]. Advanced Microeconomic Theory [19] opined that economies of scale are derived by finding the inverse of the elasticity of total cost to total production.

To derive the estimates of economies of scale, a quadratic cost function is specified in Equation (2.7). The quadratic cost function is preferred over the linear cost function because the former captures the concept of diminishing returns in the production process [17] [19]. Stated differently, the linear cost function assumes that cost increases at a constant rate per unit increase in production whiles the quadratic function assumes non-constant rate of increase in cost with production increases. To address the second objective of the study (i.e. economic analysis), the type of economies of scale present in Accra East Region of GWCL is computed as:

$$
\begin{gathered}
\ln T C_{t}=\lambda_{0}+\lambda_{1} \ln N R W_{t}+\lambda_{2} \ln Q_{t}+\lambda_{3} Q_{t}^{2}+x_{t} \\
S E=\frac{1}{\delta \ln T C / \delta \ln Q}
\end{gathered}
$$

where:

$S E=$ the type of scale economies presents;

$\ln T C_{t}=$ the natural logarithm of total cost of production;

$\ln Q_{t}=$ the natural logarithm of total production at time $t$,

$\frac{\delta \ln T C}{\delta \ln Q}=$ the cost elasticity of total production;

$\lambda_{i s}$ is the parameter estimates;

$x_{t}$ is the stochastic error term;

$\mathrm{SE}<1$ : when there decreasing returns to scale;

$\mathrm{SE}>1$ : when there are increasing returns to scale;

$\mathrm{SE}=0$ : when there are constant returns to scale.

\subsection{Data Type and Source}

Monthly time series data was used for the study. The data was collected from the headquarters of the Accra East Region of the Ghana Water Company Limited (GWCL). The data runs from January 2015 to June 2019. The data employed includes monthly total production $\left(\mathrm{m}^{3}\right)$, billed consumption, total revenue, total production cost and volume of non-revenue water $\left(\mathrm{m}^{3}\right)$.

\section{Results and Discussions}

\subsection{Summary Statistics}

Stata 14 was used to analyse the data. Table 1 presents the summary statistics of the variables used in the study. The table shows that within the $1^{\text {st }}$ month of 2015 and $6^{\text {th }}$ month of 2019 , the average NRW recorded was $2,028,907 \mathrm{~m}^{3}$ with minimum and maximum volumes of $119,300 \mathrm{~m}^{3}$ and $3,087,219 \mathrm{~m}^{3}$ respectively. How- 
ever, the deviation of NRW around the mean is estimated at $791,852.9 \mathrm{~m}^{3}$. The standard deviation is less than the mean.

Furthermore, the average production of water recorded in the region is estimated at $4,819,183 \mathrm{~m}^{3}$ with a standard deviation of $973,180.6 \mathrm{~m}^{3}$. The study further estimates the average cost of production and total revenue to be $\mathrm{GH} \$ 1,984,720$ (equivalent to $\$ 367,336.66 ; \$ 1=\mathrm{GH} \$ 5.403$ as of October 04,2019 ) and GHథ $11,225,068$ (equivalent to $\$ 2,077,562.10$ ) respectively. This result indicates a poor revenue performance of the Accra East region of GWCL. Indeed, the revenue collection ratio has been estimated at $76 \%$ [20]. This shows that several private consumers of water as well as government agencies owe GWCL.

\subsection{Trend of Non-Revenue Water in the Region}

This section analyses the trend of NRW between the $1^{\text {st }}$ month of 2015 and the $6^{\text {th }}$ month of 2019. NRW is computed as the difference between total volume of treated water and the volume of billed water expressed as a percentage. The results obtained from this analysis reveal an undulating trend of NRW over the study period. It is estimated that NRW percent averaged $40.3 \%$ over the period under consideration (see Figure 2). It can also be seen from Figure 2 that the highest NRW\% recorded was in December, 2016, where $53.03 \%$ of total production

Table 1. Summary statistics of variables.

\begin{tabular}{ccccc}
\hline Variable & Mean & Std. Dev & Min & Max \\
\hline NRW & $2,028,907$ & $791,852.9$ & 119,300 & $3,087,219$ \\
Cost & $1,984,720$ & $823,025.7$ & $393,902.8$ & $3,212,983$ \\
Production & $4,819,183$ & $973,180.6$ & $2,516,950$ & $5,874,646$ \\
Revenue & $11,225,068$ & $3,977,633$ & $3,794,197$ & $1.70 \mathrm{e}+07$ \\
\hline
\end{tabular}

Source: Authors' estimation.

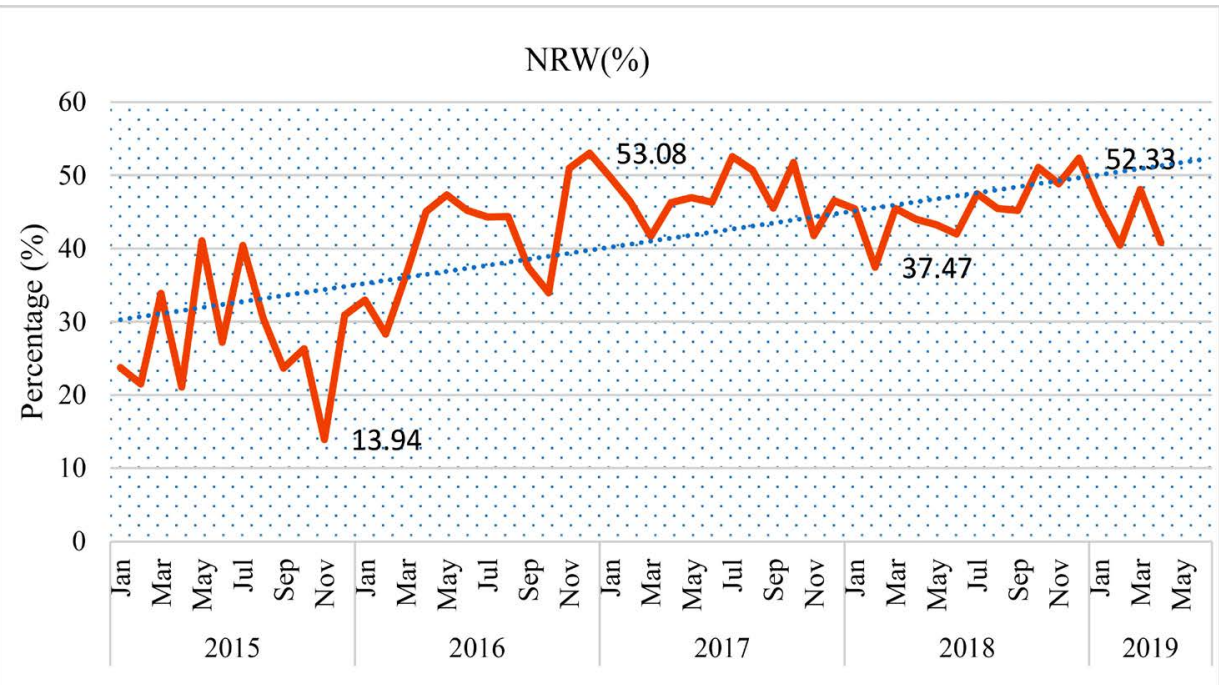

Figure 2. Trend of non-revenue water (2015-2019). 
was not billed and thus did not generate any revenue for GWCL. Also, a minimum value of $13.94 \%$ of NRW\% was recorded in November 2015. In spite of the relatively high rate of NRW, the trend line revealed steadily declining volumes of NRW over the period. It is, however, important to note that these values of NRW are far in excess of the $25 \%$ threshold accepted by the World Bank [11] [14]. Moreover, the average NRW\% of $40.3 \%$ recorded in the Accra East Region of GWCL is fairly in line with the $50 \%$ and $40 \%$ recorded in Zimbabwe and Kenya respectively [13] [20]. This indicates that African countries have a lot to do to reduce NRW in their economies.

\subsubsection{Trend in Water Production and Sales}

The study further examines the trend of volume of water produced and the volume sold to customers (see Figure 3). The results obtained show a fairly increasing trend for the production of water in the Accra East Region of GWCL. As expected, due to population growth, urbanization and increased use of water, GWCL has expanded the productive capacity to meet increasing demand. It is important to note that $2,589,310 \mathrm{~m}^{3}$ of water was produced in January 2015 . However, production has increased substantially to 4,819,183 $\mathrm{m}^{3}$ in April 2019, which represents an increase of $86.1 \%$ over the period.

Moreover, water sales have fairly increased over the period. An average of $2,776,605 \mathrm{~m}^{3}$ was sold over the period under consideration. Specifically, water volumes sold increased from $1,975,056 \mathrm{~m}^{3}$ in January 2015 to $2,776,605 \mathrm{~m}^{3}$ in June 2019 , representing an increase of $40.6 \%$. It is important to note that the growth of water production significantly exceeded growth in water sales to customers. Essentially, the difference between production and sale of water is referred to as the volume of NRW as indicated by the bars in Figure 3. It can be observed from Figure 3 that the gap between water production and sales (NRW) steadily widens over the period under consideration. This shows clearly that GWCL has to put in measures to minimize the gap.

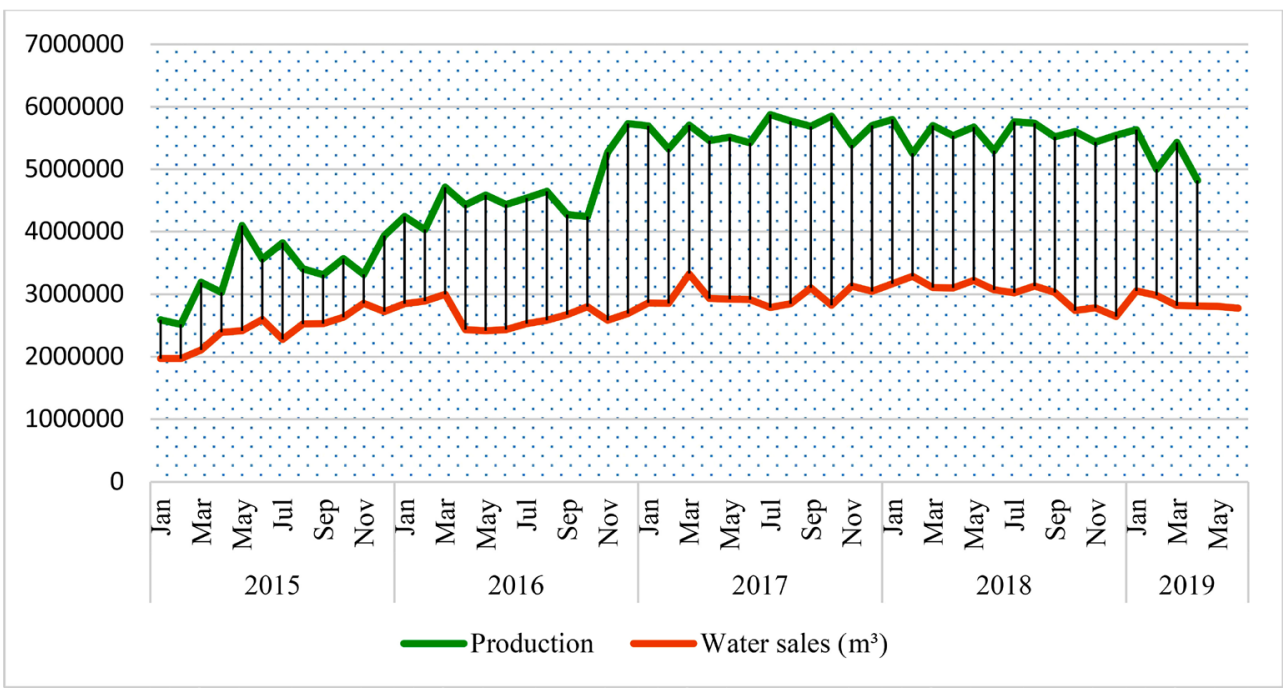

Figure 3. Trend in production and sale of water (2015-2019). 


\subsubsection{Trend in Production Cost, Billing and Revenue Collection}

This subsection examines the trend of cost of production, billing of water sold and the revenue collected. The results obtained (see Figure 4) show that an average of $\mathrm{GH} \$ 1,984,720$ (equivalent to $\$ 367,336.66$ ) has been expended by GWCL for the production of water between January 2015 and June 2019. It can be observed that the cost of production had fairly increased over time (see Figure 4). This trend can be attributed to increased volumes of water production and inflationary tendencies.

Furthermore, the results obtained show a fairly increasing trajectory of water sale billing and revenues collected. Specifically, water billing has increased steadily from $\mathrm{GH} \$ 5,330,264$ (i.e. $\$ 986,537.85$ ) in January 2015 to $\mathrm{GH} \$ 16,786,899$ (equivalently $\$ 3,106,958.91$ ) in May 2019, representing an increment of $214.9 \%$. Also, total revenue collected increased by $259.3 \%$ from GH $\$ 3,880,617(\$ 718,233.76)$ to $\mathrm{GH} \$ 13,942,192(\$ 2,580,453.82)$ over the same period. It was observed that a mean difference of GH\$5,306,098.64 $(\$ 982,065.27)$ exist which constitutes the revenue shortfall from the sale of water to customers. The results further reveal that an average revenue of $47.3 \%$ was uncollected over the period under consideration. This leaves a revenue collection gap by the Accra East Region of GWCL.

\subsubsection{Elasticity of Non-Revenue Water to Total Revenue and Production}

Table 2 presents the elasticity coefficient of NRW to total revenue (output of Equation (2.4)). The model is statistically significant at all levels with a coefficient of determination $\left(\mathrm{R}^{2}\right)$ of $83 \%$. This result has two implications. Firstly, the model can be used for policy analysis, and forecasting total revenue. Secondly, the results indicate that about $83 \%$ of the variations in total revenue can be explained by variations in NRW and production of treated water [21] [22]. The estimates show that one percent increase in the volume of NRW decreases total revenue by $0.032 \%$. In other words, total revenue and NRW are negatively related.

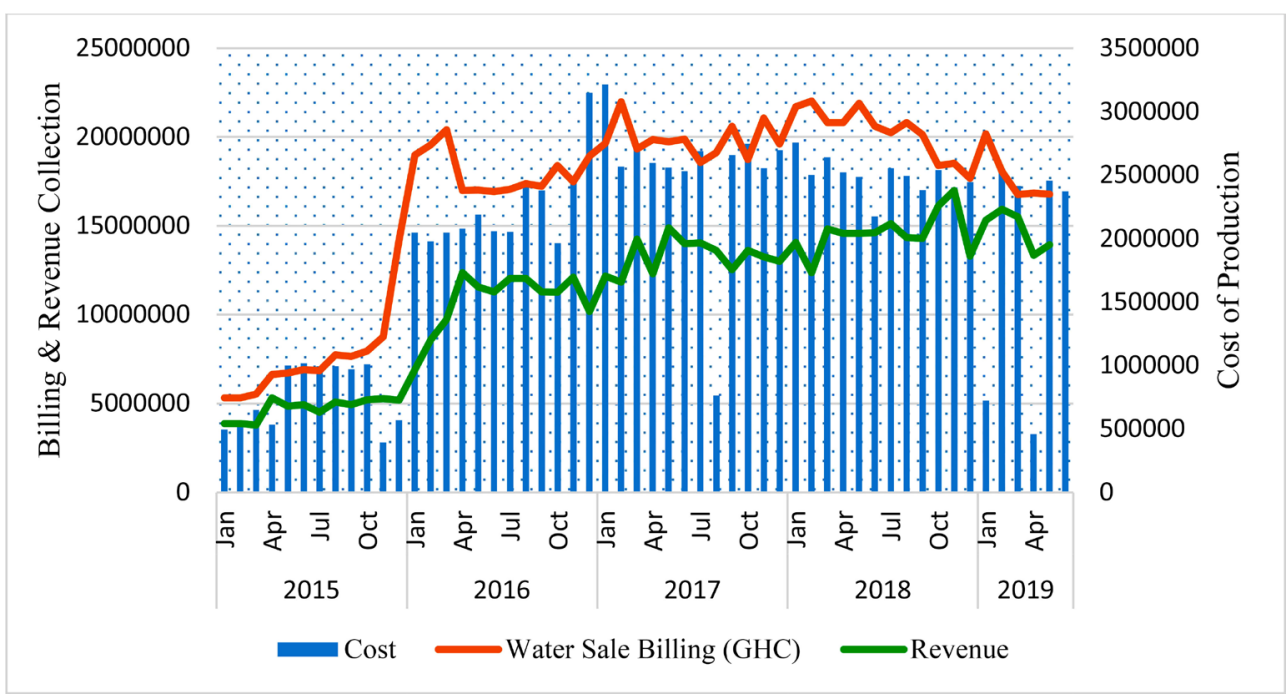

Figure 4. Trend of cost of production, billing and revenue collection. 
This finding is statistically significant at $5 \%$. It is important to note that values of NRW were captured as non-positive (see Table 2) as they do not yield revenue for GWCL. However, the estimates indicate that the relationship between the two variables is fairly inelastic. Specifically, a proportionate increase in NRW reduces total revenue by less than a proportionate amount [4] [16] [17].

Also, the study reveals that production is positively related to total revenue. A percentage increase in the volume of production of treated water increases total revenue by $1.78 \%$. This estimate is statistically significant at all levels. Likewise, this estimate is elastic. This is because increase in production will cause total revenue to increase if volumes produced are not captured under NRW. However, more revenue will be generated if GWCL sells increased volumes of treated water to customers at the prevailing tariffs [16] [23].

Furthermore, the study estimates the elasticity of NRW to total production. The results captured in Table 3 are principally the output generated from equation 2.5. The model is statistically significant at all levels with a coefficient of determination $\left(\mathrm{R}^{2}\right)$ of $73 \%$. This further indicates that about $73 \%$ of the variations in total volume of treated water can be explained by changes in the volume of NRW [21] [22].

The results obtained indicate that one percent increase in NRW increases total production of treated water by $0.32 \%$ [24]. In other words, total production and NRW are positively related. This result is statistically significant at the $1 \%$ level. The results further indicate that the relationship between total production and NRW is fairly inelastic. Indeed, [25] emphasized that reducing NRW could lead to decreased volumes of water production to meet the demands of the service area. With the assumption that households have relatively stable demand for

Table 2. Elasticity of NRW to Total Revenue.

\begin{tabular}{cc}
\hline VARIABLES & ELASTICITIES \\
\hline Non-Revenue Water & $-0.031^{\star}(0.085)$ \\
Production & $1.782^{\star * *}(0.232)$ \\
Constant & $-11.703^{\star * *}(4.468)$ \\
Observations & 51 \\
R-squared & 0.83 \\
\hline
\end{tabular}

Standard errors in parentheses; ${ }^{* *} \mathrm{p}<0.01,{ }^{* *} \mathrm{p}<0.05,{ }^{*} \mathrm{p}<0.1$; Source: authors' estimates.

Table 3. Elasticity of NRW to Total Production.

\begin{tabular}{cc}
\hline VARIABLES & ELASTICITIES \\
\hline Non-Revenue Water & $0.315^{* * *}(0.027)$ \\
Constant & $10.834^{* * *}(0.386)$ \\
Observations & 51 \\
R-squared & 0.7325 \\
\hline
\end{tabular}

Standard errors in parentheses; ${ }^{* * *} \mathrm{p}<0.01,{ }^{* *} \mathrm{p}<0.05,{ }^{*} \mathrm{p}<0.1$; Source: authors' estimates. 
water, reducing the volumes of NRW through reduced leakages could have a damping effect on production. This is because, with lesser or with even the same level of production by GWCL, customers will be satisfactorily served. However, increasing levels of NRW would require GWCL to increase production to meet the demands of their service area [13] [15].

\subsection{Type of Economies of Scale Present in GWCL}

The elasticity of production to total cost of production is presented in Table 4. The estimates indicate that a percentage increase in production increases total cost by $0.93 \%$. This shows that a fairly inelastic relationship exists between production and cost. This finding is statistically significant at $1 \%$. However, the squared term of production is statistically insignificant. Based on the estimates, the scale of economies (SE) is estimated at 1.08. In line with economic theory, this finding implies that the Accra East region (AER) of the Ghana Water Company Limited (GWCL) is experiencing diseconomies of scale [4] [5] [17] [23]. Essentially, a proportionate increase in all inputs in the production process translates into a less than proportionate increase in production of treated water. In other words, resources at the disposal of the Accra East region of GWCL are not optimally employed.

This phenomenon could be due to the high volumes of NRW recorded in the region. Also, large volumes of NRW reduce the competitiveness and efficiency of water service providers. This is because large volumes of NRW constrain the financial ability of utility companies to embark on network expansion and meter replacement policies which enhances revenue of the company [4] [7] [12] [26].

\section{Conclusions}

Non-Revenue Water has been a bane in the quest to engender efficiency, sustainability of water production and management and competitiveness in the operations of the Accra East region of GWCL. The most significant deduction that can be made from the study is that NRW averaged $40.3 \%$ over the period under consideration, which far exceeds the $25 \%$ threshold accepted by the World Bank for developing economies at the Accra East region of the GWCL. This result is Table 4. Type of Economies of Scale.

\begin{tabular}{cc}
\hline VARIABLES & ELASTICITIES \\
\hline Non-Revenue Water & $0.081(0.156)$ \\
Production & $0.929^{* * *}(0.479)$ \\
Squared production & $-1.082(0.680)$ \\
Constant & $-15.330^{* * *}(4.745)$ \\
Observations & 51 \\
R-squared & 0.635 \\
\hline
\end{tabular}

Standard errors in parentheses; ${ }^{* * *} \mathrm{p}<0.01,{ }^{* *} \mathrm{p}<0.05,{ }^{*} \mathrm{p}<0.1$; Source: Authors' estimates. 
worrying and calls for the development and implementation of appropriate measures to mitigate the effects of this huge gap in NRW on the operations of the AER of GWCL. Results further revealed that a fairly inelastic relationship exists between NRW and total revenue as well as between NRW and volume of production. Finally, the study finds that resources are not optimally used in the Accra East region of GWCL as proof of diseconomies of scale was established making the company not competitive financially.

Based on the evidence of shortfalls suggested by the findings of this research and conclusions arrived at, the study makes the following recommendations:

- Monitoring and evaluation practices should be intensified by GWCL to minimize the volume of NRW in the region. Task force from GWCL should periodically conduct checks on households to ascertain the accuracy of meter readings, issues regarding meter bypass and illegal connections in communities. To this effect, GWCL should develop and assemble watchdog committees in various communities to help clamp down on illegal connections and issues of meter bypasses. This is because, these individuals live in the communities and have evidence of households who engage in these malpractices.

- The Government of Ghana should also design policies that would clear debt owed the GWCL and pay for its share of unbilled authorized consumption. An agreement should be reached between GWCL and government which would ensure meter installations at government agencies which do not pay for water. This would engender responsible water use and reduce the volumes of NRW.

- The GWCL should also embark on extensive meter installation project to replace dilapidated meters and also abolish the system of flat rate billing. These initiatives would minimize inaccuracies in meter registration and ensure that households that use more water, pay more. Effective implementation of this strategy would improve on revenue generation of GWCL.

- Finally, efforts must be directed at retrieving monies owed GWCL by customers. It has been evident from the study that revenue collection has been appalling within the Accra East region of GWCL. Efforts must be made to institute a prepaid system of water usage to minimize debts owed GWCL. A pilot study can be adopted in one of the districts to ascertain the performance of the prepaid system. Upon successful implementation, the exercise can be replicated in other regions.

\section{Acknowledgements}

The authors are profoundly grateful to Mr. Abraham Kwarteng (Regional Commercial Manager, Accra East Region), Mr Alexander Bonney (Regional Commercial Officer, Accra East Region) and Mr. Jerry Pecku (Head, MIS Department, Accra East Region) for willingly making revenue data available for the purpose of this study. The authors also wish to express their heartfelt gratitude to Ms. Akua Opesa (Chemist, Water Quality Department) at the Kpong Head- 
works for the provision of chemical consumption data, Mr. Promise Anopansio (Assistant Accountant, ATMA Production) and Ms. Peace Foli (Finance Officer, ATMA Production) for the provision of data regarding the volumes of water input to the Accra East Region as well as Mr. Ben Ameko (Assistant Head, Technical Secretariat, ATMA Production Region) for provision of electricity consumption data.

\section{Funding}

This research did not receive any specific grant from funding agencies in the public, commercial, or not-for-profit sectors.

\section{Conflicts of Interest}

The authors declare no conflicts of interest regarding the publication of this paper.

\section{References}

[1] Hu, D. (2006) Water Rights. An International and Comparative Study. IWA, London. https://www.iwapublishing.com/books/9781843391081/water-rights

[2] Mountford, H. (2011) Water: The Environmental Outlook to 2050. OECD Global Forum on Environment: Making Water Reform Happen, Paris, 25-26 October 2011, 1-21. https://www.oecd.org/env/resources/49006778.pdf

[3] Report of the Secretary-General, Special Edition: Progress towards the Sustainable Development Goals. https://sustainabledevelopment.un.org/sdg6

[4] Appiah, K., Du, J. and Sarpong, P.B. (2017) Non-Revenue Water Management in Ghana: The Opportunities and Challenges. Journal of Environment and Earth Science, 7, 59-67.

[5] GWCL (2018) Ghana Water Company Limited Proposals for Review of Aggregate Revenue Requirement and Tariff. https://www.gwcl.com.gh/tarrif_paper.pdf

[6] Aqua Vitens Rand Ltd. (2007) Annual Report 2007. Accra. https://en.wikipedia.org/wiki/Water_privatisation_in_Ghana

[7] Yeboah, P. (2008) Management of Non-Revenue Water: Case Study of the Water Supply in Accra, Ghana. Unpublished Master of Science Thesis, Water Engineering and Development Center, Department of Civil and building Engineering, University of Loughborough, Loughborough, 11-16.

http://www.switchurbanwater.eu/outputs/pdfs/W3-1_CACC_PHD_Management_o f_Non-Revenue_Water_-_Case_study.pdf

[8] International Water Association (2003) Managing Leakage by Managing Pressure. Practical Approach.

[9] Maina, M. (2010) Determinants of High Non-Revenue Water: A Case of Water Utilities in Murang'a County, Kenya. An Unpublished Dissertation, Kenyatta University, Nairobi.

[10] (2010) Ghana Water and Sanitation Sector Performance Report. Ministry of Water Resources, Works and Housing, Accra, 16-83.

https://www.washghana.net/sites/default/files/0993402f3e475dae0fbfb5f51a762723. pdf

[11] Kingdom, B., Liemberger, R. and Marin, P. (2006) The Challenge of Reducing 
Non-Revenue Water (NRW) in Developing Countries-How the Private Sector Can Help: A Look at Performance-Based Service Contracting. Water Supply and Sanitation Sector Board Discussion Paper Series, Vol. 1, No. 8 (Report 39405), The World Bank, Washington DC, 1-52.

[12] Farley, M., Ghazali, Z., Istandar, A., Singh, S. and Wyeth, G. (2008) The Manager's Non-Revenue Water Handbook a Guide to Understanding Water Losses. USAID, Washington DC.

[13] Kanosvamhira, T. and Matsa, M. (2017) The Determinants of Non-Revenue Water in Surugwi Town: A Case of Makusha Residential Area. Journal of Sustainable Development in Africa, 19, 92-104.

[14] Shilehwa, C. and Gakuu, C. (2016) Factors Influencing Water Supply's Non-Revenue Water Supply Scheme. International Journal of Management and Commerce Innovations, 4, 735-743.

[15] Criminisi, A., Fontanazza, G., Freni and La Loggia, G. (2009) Evaluation of the Apparent Losses Caused by Water Meter Under-Registration in Intermittent Water Supply. Water Science and Technology, 60, 2373-2382.

https://doi.org/10.2166/wst.2009.423

[16] Varian, H.R. (1992) Microeconomic Analysis. Third Edition, W.W. Norton and Company, Inc., New York, 1-22.

http://www.apmath.spbu.ru/ru/staff/kuzyutin.d/files/Varian_Hal___Microeconomi c_Analysis_3d_edition__1992.pdf

[17] Nicholson, W. and Synder, C. (2008) Microeconomic Theory: Principles and Extensions. Tenth Edition, Thomson Higher Education, New York, 3-83.

https://edisciplinas.usp.br/pluginfile.php/2871502/mod_resource/content/1/Nichols on $\% 20 \% 20$ Snyder\%20\%282007\%29\%20-\%20Microeconomic\%20theory\%20-\%2010 \%20ed..pdf

[18] Cameron, S. (1994) A Review of the Econometric Evidence on the Effects of Capital Punishment. Journal of Socio-Economics, 23, 197-214.

https://doi.org/10.1016/1053-5357(94)90027-2

[19] Jehle, G. and Reny, P. (2011) Advanced Microeconomic Theory. 3rd Edition, Financial Times Prentice Hall, London.

[20] Hailu, D., Rendtorff-Smith, S. and Tsukada, R. (2011) Small-Scale Water Providers in Kenya: Pioneers or Predators. United Nations Development Programme, Poverty Reduction and Environment and Energy, New York, 2-35. https://www.undp.org/content/dam/undp/library/Poverty\%20Reduction/Inclusive \%20development/Kenya\%20paper(web).pdf

[21] Gujarati, D.M. (2003) Essentials of Econometrics. 3rd Edition, McGraw-Hill International, New York.

[22] Greene, W.H. (2008) Econometric Analysis. 6th Edition, Prentice-Hall, Upper Saddle River.

[23] Mas-Colell, A.M. (1995) Microeconomic Theory. Oxford University Press, New York.

https://labs.xjtudlc.com/labs/wldmt1/books/Economics\%20and\%20game\%20theory /Microeconomic\%20Theory.pdf

[24] Decker, C.W. and Jordan, L.A. (2006) Managing Water Losses in Amman's Renovated Network: A Case Study. Management of Environmental Quality: An International Journal, 17, 94-108. https://doi.org/10.1108/14777830610639468

[25] Trow, S. (2005) Alternative Approaches to Setting Leakage Targets. In: Proceedings of Water Loss Conference Bucharest, International Water Association, Romania, 
75-85.

[26] Pearson, D. and Trow, S.W. (2005) Calculating Economic Levels of Leakage. Proceedings of Leakage 2005 Conference, Halifax, 1-16.

\section{Acronyms}

ATMA Accra-Tema Metropolitan Area

AER Accra East Region

GWCL Ghana Water Company Limited

GWSC Ghana Water and Sewerage Corporation

IWA International Water Association

NRW Non-Revenue Water

OLS Ordinary Least Squares

PURC Public Utilities Regulatory Commission

SABESP Saneamento Básico do Estado de São Paulo

WASH Water Sanitation and Hygiene

WB World Bank

WHO World Health Organization

WRC Water Resource Commission 